\title{
The departure of the hero in a ship: The intertextuality of Beowulf, Cynewulf and Andreas ${ }^{1}$
}

\author{
Francis Leneghan \\ University of Oxford
}

This article identifies a new Old English poetic motif, 'The Departure of the Hero in a Ship', and discusses the implications of its presence in Beowulf, the signed poems of Cynewulf and Andreas, a group of texts already linked by shared lexis, imagery and themes. It argues that the Beowulf-poet used this motif to frame his work, foregrounding the question of royal succession. Cynewulf and the Andreas-poet then adapted this Beowulfian motif in a knowing and allusive manner for a new purpose: to glorify the church and to condemn its enemies. Investigation of this motif provides further evidence for the intertextuality of these works.

Keywords: Old English poetry; Beowulf, Cynewulf; Andreas; Anglo-Saxon literature

\section{Introduction}

Scholars have identified a number of 'motifs', 'themes' or 'type scenes' in Old English poetry. Two of the best-known such motifs are 'the beasts of battle', typically featuring the carrion eagle, wolf and raven, anticipating or rejoicing in slaughter (Magoun 1955, Bonjour 1957, Griffith 1993), and 'the hero on the beach', wherein a hero is depicted with his retainers in the presence of a flashing light, as a sea-journey is completed (or begun), usually at dawn

${ }^{1}$ I would like to thank Daniel Anlezark, Hugh Magennis, Richard North, Andy Orchard, Rafael Pascual and Daniel Thomas for their helpful comments on earlier versions of this article.

Francis Leneghan, Selim24 (2019): 105-132.

ISSN 1132-631X / DOI https://doi.org/10.17811/selim.24.2019.105-134 
(Crowne 1960: 368; Fry 1966, 1971). ${ }^{2}$ Broadening the focus to consider both Old English verse and prose, Mercedes Salvador Bello identified the 'leitmotif of 'the arrival of the hero in a ship' in the Anglo-Saxon Chronicle and Beowulf, featuring "a recurrent thematic pattern which presents the story of the heroes (or the hero) who arrive from northern lands in a boat and become the ancestors of Anglo-Saxon dynasties" (1998: 214). This article contributes to this avenue of research by identifying a new Old English poetic motif, termed here 'the departure of the hero in a ship'. The salient features of this motif are as follows:

(1) the presence of grieving retainers

(2) the accompaniment of the departing hero to the shore

(3) a description of an awaiting ship

(4) the loading of treasure

(5) praise of the departing hero

In some instances, this motif is embellished by the presence of two further narrative elements: (6) the hero's vessel is given to the sea, and (7) the narrator's expression of wonder at the splendour of the hero's departing vessel. In the cases discussed here, these various elements do not necessarily appear in the same order; poets freely re-arranged them to suit their specific purposes.

Of particular interest is the commonality of this motif to a group of closely-related Old English poems, namely Beowulf, two of the four signed poems of Cynewulf (Elene and Juliana) and Andreas. Traditionally, the presence of common themes or motifs in two or more Old English poems has been explained by the theory of a common stock of (oral)-formulaic scenes that all Anglo-Saxon poets could draw on (e.g. Crowne 1960). Any resemblance in phrasing and imagery between texts was therefore to be accounted for as simply reflexes of a common oral tradition. However, there is now increasing evidence to suggest that at least some Anglo-Saxon poets working in the vernacular not only directly quoted or borrowed from each

\footnotetext{
${ }^{2}$ Further examples include 'the traveller recognises his goal' (Clark 1965) and 'sleeping after the feast' (McFadden 2000, Battles 2015). All quotations from Beowulf are taken from Fulk, Bjork \& Niles (2008). All citations from other Old English poems are from ASPR, except Andreas, which is cited from North \& Bintley (2016). I have silently hyphenated compounds and inserted macrons to indicate vowel-length. Translations are my own unless otherwise stated.
} 
other's work, but also sometimes engaged in sophisticated acts of literary allusion and intertextuality, in a manner comparable to contemporary poets composing in Latin (Orchard forthcoming). ${ }^{3}$ The term 'intertextuality' was first employed by Julia Kristeva (1986: 37) to theorise the relationship between texts: "any text is constructed as a mosaic of quotations; any text is the absorption and transformation of another". Gérard Genette (1997: 1-2) defines intertextuality as "a relationship of copresence between two or among several texts: that is to say [...] the actual presence of one text within another" (emphasis added). ${ }^{4}$ This article will argue that the 'co-presence' of 'the departure of the hero in a ship' in Beowulf, the signed poems of Cynewulf, and Andreas strengthens the case for the intertextuality of this group of texts and provides further evidence for how both Cynewulf and the Andreas-poet absorbed and transformed Beowulf.

\section{Beowulf}

The motif of 'the departure of the hero in a ship' appears most frequently in Beowulf, a work in which, as John Hill (2008: 5) has demonstrated, the action revolves around scenes of auspicious arrival and departure. The first instance forms a major part of the description of the ship-funeral of Scyld Scefing that, in the view of many commentators, serves as a 'prologue' to the work:

Him ðā Scyld gewāt tō gescæp-hwìle

fela-hrōr fēran on frēan wǣre.

Hī byne pā atbēron tō brimes faroðe,

swēse gesī

penden wordum wēold. Wine Scyldinga,

lèof land-fruma lange āhte -

\footnotetext{
${ }^{3}$ See further Alfaro (1996). On similarities between the techniques used by poets composing in Old English and Latin in this period, see Benson (1995) and Orchard (forthcoming).

${ }^{4}$ Genette (1997: 2) identifies three distinct forms of intertextuality: quotation, plagiarism ('undeclared but literal borrowing'), and allusion, the last of which he defines as "an enunciation whose full meaning presupposes the perception of a relationship between it and another text, to which it necessarily refers by some inflections that would otherwise remain unintelligible".
} 
pār at hȳðe stöd, bringed-stefna

isig ond ütfüs - epelinges fer;

àlēdon pà lēofne pēoden,

bēaga brytttan on bearm scipes,

mǣrne be mæste. $\bar{p}_{\bar{e}} \bar{r}$ was mādma fela

of feor-wegum fretwa gelēded.

Ne bȳrde ic cȳmlicor cēol gegyrwan

bilde-wēpnum ond beaðo-wēdum,

billum ond byrnum; him on bearme leg

mādma manigo, $\quad b \bar{a}$ bim mid scoldon

on flödes ēbt feor gewītan.

Nalæs hī hine lǣssan lācum tēodan,

pēod-gestrēonum, ponne pā dydon

pē hine æt frumsceafte forð onsendon

$\bar{x}$ nne ofer ȳðe umborwesende.

pà gỳt hìe him āsetton segen gyldenne

hēah ofer hēafod, lèton hom beran,

gēafon on gār-secg; bim wes geōmor sefa,

murnende mōd. Men ne cunnon

secgan tō sōðe, sele-rǣdende,

hæleð under heofenum, hwā $p \bar{x}$ hlæste onfēng.

(Beowulf, 26-52) (emphasis added)

[Then Scyld departed at the appointed time, journeyed far, very strong, into the Lord's keeping. They carried bim to the edge of the sea, dear retainers, as he himself had instructed while he still had the power of speech. The Lord of the Scyldings, beloved land-ruler, held power for a long time - there at the shore stood a ring-prowed ship, icy and eager to set out - the atheling's ship; they laid therein the beloved prince, giver of rings, in the bosom of the ship, glorious by the mast. There was a great deal of treasures, ornaments piled up from far away. I never beard of a comelier ship strewn with war-weapons and battle-gear, swords and mailcoats; they placed onto his bosom many treasures, that would travel far with him into the embrace of the flood. Not at all did they provide him with fewer gifts, treasures of the people, than did those who sent him forth in the beginning, alone over the waves, while still a child. They set a golden sail high over his head, let the sea take him, gave him to the ocean. They were sad at heart, grieving in spirit. Men could not truly say, hall-counsellors, warriors under the heavens, who received that cargo.] 
In this famous passage, all the key elements of the motif are present, artfully combined to create a memorable and moving account of the funeral of a great Danish king: the departing hero is accompanied to the shore (28-29a) and praised (30b-31a); his awaiting ship is described (32-33); the narrator expresses his wonder ( $N e$ byrde ic) at the sheer extent of the many treasures that are loaded into the ship $(36 \mathrm{~b}-46) ;^{5}$ the vessel is committed to the sea (48b-49a); and the hero is mourned by his grieving retainers (49b-50a).

The Beowulf-poet then varies this theme in the much shorter description of the hero's own departure from the Geats as he sets out to confront Grendel (205-212a). In this scene, the hero is again accompanied by his own troops to the shore (205-208a) and the prow of the ship is described (212a). ${ }^{6}$ Given the optimistic mood of the scene, there is no mention of grief at Beowulfs departure; on the contrary, we are told that the Geats did not try to dissuade him from this journey but rather offered him encouragement (202-204). ${ }^{7}$

A second minor variation of this motif, now in a tragic key, appears in the account of Queen Hildeburh's departure from Frisia that forms the conclusion to the 'Finnsburg Episode'. The queen is accompanied to the shore by Sceotend Scyldinga, 'the bowmen of the Scyldings' (1154a) and placed in a ship together with treasures (1154-1159a). However, on this occasion, there is no description of the ship itself, nor of any grieving individuals gathered on the shore, or words of praise for the departed. The marked absence of these

\footnotetext{
${ }^{5}$ See below for echoes of this half-line in Elene and Andreas.

${ }^{6}$ The ship's prow is twice referred to in the subsequent account of Beowulf's sea voyage (218a, 220a). For discussion of this passage, together with other sea voyages in Beowulf, see Ramsey (1971).

${ }^{7}$ For parallels between Scyld's funeral and that of the Breton St Gildas, see Cameron (1969) and Meaney (1988). For discussion of comparable departure scenes in Germanic literature, see Classen (2012). On Homeric departure scenes (often involving libation), see Greene (1995). A particularly striking Anglo-Latin parallel to Scyld Scefing's funeral has recently been noted by Henrietta Leyser (2017: 54) in the descriptions of Abbot Ceolfrith's departure for Rome contained in Bede's Lives of the Holy Abbots of Wearmouth and Jarrow, ch. 17 (Grocock \& Wood 2013: 62-65) and the anonymous Life of Abbot Ceolfrith, chs. 26-27 (Grocock \& Wood 2013: 104-107). Both these accounts share several elements of the motif of 'the departure of the hero in a ship', as defined in this article: the departing hero, Ceolfrith, is accompanied to the shore by his 'retainers', who grieve and offer songs of praise; together with his retainers, the hero boards the ship, which is loaded with treasures (candles and a golden cross, as well, of course, as the Codex Amiatinus, though this is not mentioned in either text).
} 
elements fits the sombre mood of the passage: in contrast to Scyld's impressive dynastic legacy in the form of his son, Beow, Hildeburh leaves behind her only the wreckage of royal family destroyed by feuding.

The first major variation of 'the departure of the hero in a ship', however, occurs in the description of the Geatish hero's departure from the Danes after his victories over the Grendelkin:

Gecyste $p \bar{a}$ cyning apelum gōd,

pēoden Scyldinga yegn betestan

ond be healse genam; bruron bim tēaras

blonden-feaxum. Him wæs bēga wēn

ealdum infrōdum, ōpres swīðor,

pæt hīe seoððan nō gesēon mōston,

mōdige on meple. Wes him se man tō pon lēof

pat he pone brēost-wylm forberan ne mebte,

ac bim on brepre byge-bendum fast

after dēorum men dyrne langað

born wið blōde. Him Bēowulf panan,

gūo-rinc gold-wlanc græs-moldan træd

since hrēmig; sēgenga bād

āgend-frean, sē pe on ancre rād.

pā wæs on gange gifu Hrōðgāres

oft gexhted; pat wes ān cyning

æoghwæs orleahtre, op pæt hine yldo benam

mægenes wynnum, sē pe oft manegum scōd.

Cwōm pā tō flōde fela-mōdigra,

beg-stealdra bēap, bring-net bēron,

locene leoðo-syrran. Land-weard onfand

eft-sīo eorla, swā hē ǣr dyde;

nō hē mid hearme of hliðes nōsan

gæstas grētte, ac him tōgēanes rād,

cwæð pæt wilcuman Wedera lēodum

scapan scīr-hame tō scipe fōron.

pā wes on sande sēéeap naca

bladen bere-wēdum, bringed-stefna

mēarum ond māðmum; meste blīfade

ofer Hrōogāres hord-gestrēonum.

Hē pǣm bāt-wearde bunden golde 
swurd geš̄lde, pært hē syðopan wæs on meodu-bence māpme bȳ weorbra, yrfe-lāfe. Gewāt him on naca drēfan dēop wæter, Dena land ofgeaf. (Beowulf, 1870-1904) (emphasis added)

[Then that good king, of noble ancestry, lord of the Scyldings, kissed the best of thanes, grasped him by the neck; that grey-baired man shed tears. That very wise and old man was in two minds - but he knew it was most likely that they would never see each other again, brave in the meeting-place. That man was so dear to him that be could not prevent the welling of his heart, but secure in the thoughts of his breast a deep and secret longing for that dear man burned against his blood. From there Beowulf took himself away, trod the grassy earth, the battlewarrior rejoicing in gold, exultant man; the sea-goer awaited its lordly owner, the one who rested at anchor. Then the gift of Hrothgar was often praised during the departure; that was a king without match, always blameless, until old age deprived him of the joys of strength, he who often injures so many.

Then they came to the water, many brave ones, a gathering of young warriors, carrying ring-nets, locked mail-shirts. The coastguard observed the return of the men, just as he did before; he did not greet the guests with insults from the edge of the cliff, but he rode towards them, and said that the warriors in their shining armour were welcome to travel to their ships, people of the Weders. Then the sea-curved prow was on the sand, the ring-necked ship, laden with battlegear, horses and treasures; the mast towered above, over Hrothgar's treasure-hoard. He gave that boat-guardian a sword of bound gold, so that afterwards he was always the more honoured on the mead-benches because of the ancient heirloom. They went into the boat, drove across deep water, departed from the land of the Danes.]

As in Scyld's departure-scene, the hero is accompanied to the shore (1888$1890 \mathrm{~b})$ to an awaiting ship (1182b-1183), into which treasures are placed (1896-1899). However, while in the first scene the Danes grieve at their king's departure, now it is the old Scylding ruler, Hrothgar, who mourns the young hero's leave-taking (1870-1880a). ${ }^{8}$

\footnotetext{
${ }^{8}$ For further discussion of the dynastic implications of Beowulfs departure from the Danes, see Hill (2008: 61-64) and Leneghan (forthcoming).
} 


\section{Francis Leneghan}

The second major variant of the 'the departure of the hero in a ship' in Beowulf appears in the linked funerals of the dragon and King Beowulf that form the poem's conclusion:

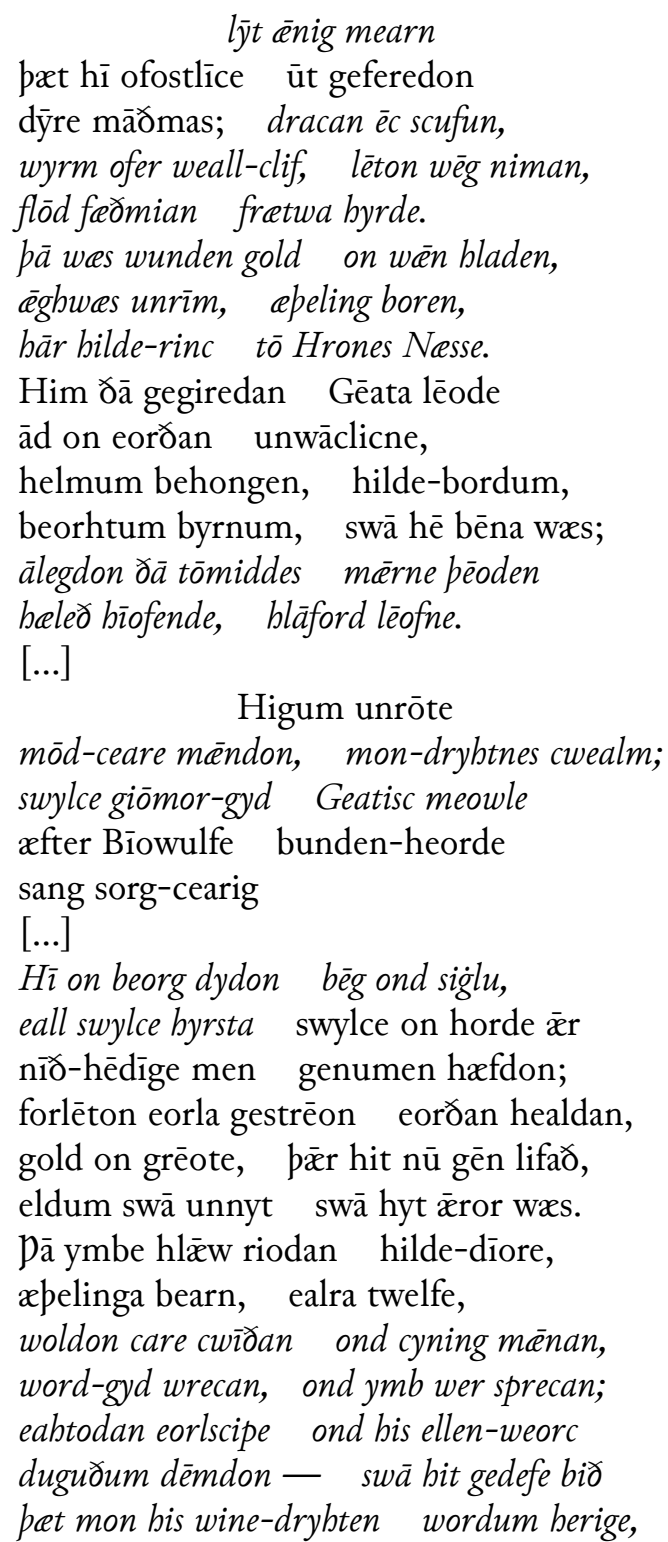


ferbðum frēoge, ponne hē forð scile of līc-haman līeded weorðan.

Swā begnornodon Géata lēode

blāfordes bryre, beorð-geneatas;

cwēdon pat bē wēre wyruld-cyninga

manna mildust ond monðwērust,

lēodum līðost ond lofgeornost.

(Beowulf, 3129b-3142, 3148b-3152a, 3163-3182) (emphasis added)

[There was no mourning when they quickly went out with valuable treasures; they also pushed the dragon, the serpent, over the sea-cliff, let the waves take bim, the guardian of those treasures, the embrace of the flood. Then that wound gold was loaded onto wagons, an immeasurable amount, the etheling was carried, greybarried battle warrior, to Hronesnass. The people of the Geats made for him a sturdy funeral pyre on the earth, hung with helmets and battle-shields, shining mail-coats, as he had instructed; they laid their illustrious prince in the middle, the warriors lamenting their beloved lord. [...] They lamented their mind-sorrow with heavy spirits, the death of their liege lord; likewise, a Geatish woman, her hair bound, miserably sang a sorrowful song in memory of Beowulf. [...] They placed on the barrow rings and treasures, all such plunder as desperate men had previously taken from the hoard; they let the earth hold the treasures of warriors, gold in the dirt, where it still lives now, as useless to men as it was before. Then they rode around the barrow, battle-brave ones, sons of athelings, twelve in all, they wished to lament their sorrow and mourn their king, to recite tales, and to speak about the man; they praised his nobility and bis glorious deeds, bonoured bis acbievements —in such a way as is fitting for a man to praise with words bis dear lord, love bim in the heart, when he must be led forth from the body. So the men of the Geats lamented the fall of their lord, hearth-companions; they said that of all the kings of the world he was the mildest of men, and the most gentle, the kindest to the people, and the most eager for fame.]

As in the previous two departure scenes, the corpses of both the dragon and the hero are brought to the shore (3131b-3133, 3134-3136). Naturally, the Geats shed no tears as they commit the hated dragon's carcass to the waves (3129-3133), while they greatly mourn the loss of their beloved king (3148b3150), laying treasures alongside him on his barrow (3137-3142, 3163-3168) and praising his great achievements and many virtues (3168-3182). In place of the splendidly decorated ships that accompanied the previous sea-borne 
departures of Scyld and Beowulf, now a magnificent funeral pyre on a sea-cliff stands waiting to consume the hero's body (3137-3148a). ${ }^{9}$

From this brief discussion, it will be clear that the Beowulf-poet structured his work around major and minor variations of the motif of 'the departure of the hero in a ship'. By varying the constituent elements of the motif, the poet achieved subtle and complex contrasts and associations that serve as links between key moments in the 'dynastic drama..

\section{The signed poems of Cynewulf}

Cynewulf appears to have made extensive use of Beowulf to assist in the process of adapting his Christian-Latin sources into the medium of Old English verse, borrowing from the secular heroic poem a number of words, phrases and themes (Sarrazin 1886, 1888; Schaar 1956: 304-305; Orchard 2003a). Further evidence of Cynewulfs engagement with Beowulf can also be detected in his imaginative adaptation of the motif of 'the departure of the hero in a ship' in order to glorify God's disciples and saints. While it remains possible that Cynewulf's use of this motif is indebted to other, unknown sources, the close links already established between his works and Beowulf supports the theory of a direct textual link in this instance.

Cynewulfs most elaborate use of this motif is found in Elene, a celebration of the recovery of the True Cross by the mother of the Emperor Constantine preserved in the Vercelli Book. The closest Latin analogue, the Acta Cyriaci or Inventio Crucis, simply describes how, after receiving an inspirational vision of the Cross on the eve of a battle, Constantine studied the gospels and sent his mother to Jerusalem to find the true Cross: ${ }^{11}$

2. [...] Cum didicisset autem a sanctis Euangeliis ubi esset Dominus crucifixus, misit 1 suam matrem Helenam ut exquireret sanctum lignum Crucis Domini, $\&$ in eodem loco ædificaret ecclesiam. [...] hæc autem in omnibus Scripturis se

\footnotetext{
${ }^{9}$ As Gale Owen-Crocker (2000: 227) has noted, the perspective of seafarers passing Beowulf s barrow (3156-3158) mirrors that of the Danes who, in the opening scene, mournfully gaze after Scyld's departing ship.

${ }^{10}$ See further Leneghan (forthcoming).

11 On the sources of Elene, see Gardner (1970), Calder \& Allen (1976: 59-60), Borgehammar (1991) and Gradon (1996: 5-22).
} 
exercebat, \& nimiam in Domino nostro Jesu Christo possedit dilectionem: postmodum \& salutare sanctæ Crucis lignum exquisivit. Cum legisset autem intente adventum humanitatis Salvatoris nostri Jesu Christi \& crucis ejus assumptionem $\&$ a mortuis resurrectionem, non est moras passa donec victoriæ Christi invenit lignum, ubi dominicum \& sanctum fixum est corpus. (Acta Sanctorum, Maius, Tom. I, 1680: col. 445D)

[When he had learned from the Holy Evangelists where the Lord had been crucified, he sent his mother, Helena, to seek the holy wood of the Lord's Cross and to build a church in the same place. She studied all the Scriptures, had exceeding love for our Lord Jesus Christ and afterwards sought for the life-giving wood of the Holy Cross. When she had read attentively about the coming of our Jesus Christ, the Saviour of mankind, His Crucifixion on the Cross, and Resurrection from the dead, she lost no time till she found the wood of Christ's victory, upon which the Lord and Saviour's body had been nailed.]

Cynewulf, by contrast, produces a greatly expanded departure-scene in which Elene is accompanied to the shore by a band of warriors to a place where a ship stands waiting; treasure is then loaded onto the ship as the departing heroine is praised by the onlookers:

Ongan pā ofstlīce eorla mengu

tō flote fȳsan. Fearoð-bengestas

ymb geofenes steð gearwe stōdon,

sālde s̄e-mēaras, sunde getenge.

Đā wæs orcnǣwe idese sīofæt,

siððan wǣges helm werode gesōhte.

pēr wlanc manig æt Wendel-š̃

on stæðe stōdon. Stundum wrǣcon

ofer mearc-paðu, mægen æfter ōorum,

ond pā geblödon bilde-sercum,

bordum ond ordum, byrn-wīgendum,

werum ond wîfum, wēe-bengestas.

Lēton pā ofer fîfel-wǣg fāmige scrīoan

bronte brim-pisan. Bord oft onfēnng

ofer earh-geblond $\bar{y}$ ða swengas;

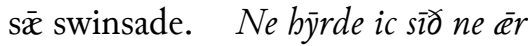

on èg-strēame idese lēdan, 
on mere-strēte, magen fägerre.

(Elene, 225-242) (emphasis added)

[Many warriors then began hastily to burry to the sea. Billow-stallions stood ready at the shore of the ocean, sea-horses moored, beside the water, then the royal woman's journey was made known, once she sought the ocean waves with a troop. There was many a proud one standing on the shore by the Wendel Sea. Sometimes they advanced over border paths, one strong one after the other, and then loaded the wave-stallions with battle-shirts, shields and spears, mail-coated warriors, men and women. Then they let the sea vessel glide over the foamy way of giants. The boards often received the swinging of waves over the mingling of oars; the sea roared. I never heard before nor since of a royal woman leading a fairer force on the water stream, across the sea's riding.]

Cynewulf's account of Elene's departure displays many of the same features of the motif of 'the departure of the hero in a ship' highlighted above in Beowulf. In further echoes of Scyld's departure scene, Elene's ship is committed to the sea (234-236), while the narrator expresses wonder (Ne by rde ic, 240b) at the splendour of the departing heroine and her group. ${ }^{12}$ Moreover, Cynewulf appears to have adapted the Beowulfian motif of the loading of the ship with treasure to describe how Elene is accompanied on to her ship not only by weapons (Elene 234b-235: bilde-sercum/ bordum ond ordum, byrn-wīgendum; cf. Beo 39-40a: bilde-wēpnum ond heaðo-wēdum/ billum ond byrnum $)^{13}$ but also by people (Elene 36a: werum ond wifum). As we shall see, the Andreas-poet was alert to this Cynewulfian repurposing of Beowulf and offered his own imaginative variation on this motif in his description of the loading of St Andrew's ship on its departure from Achaia. In a significant variation of the motif, as with the description of Beowulfs departure from the Geats, the absence of grief at Elene's leave-taking is accounted for by the optimistic mood of the journey at hand. ${ }^{14}$

\footnotetext{
${ }^{12}$ The phrase ne bỹrde ic only occurs four times in the extant corpus of Old English poetry, twice in Beowulf (38a and 1842b), and once each in Elene (240b) and The Menologium (101a).

${ }_{13}^{13}$ Both beaðo-wēdum (Beo 39b) and bilde-sercum (Elene 234b) are unique compounds.

${ }^{14}$ The case for Cynewulfs direct use of Beowulf here is strengthened by further parallels between the account of Elene's voyage and arrival in Jerusalem (233b-275), in her bringed-stefnan, 'ring-prowed' ship (248b), and Beowulf's voyage from Geatland and arrival in Denmark (217-233). The compound bringed-stefna only occurs here and
} 
Another, shorter variation on this motif appears towards the end of Cynewulfs Juliana, a saint's life copied in the Exeter Book and based on a Latin source thought to resemble that preserved in the anonymous Acts of Saint Juliana. ${ }^{15}$ This analogue concludes with a brief account of the drowning of the saint's wicked tormentor, the governor Eleusius, and his men:

Præfectus autem Eleusius, cum nauigasset in sua suburbano, uenit tempestas ualida, et mersit nauem ipsius, et mortui sunt uiri numero .xxxiiiii. Et cum iactasset eos aqua in locum desertum, sic ab auibus et feris corpora eorum deuorata sunt. Passa est autem sancta Iuliana .xiiii. kalemdarum Martiarum a præfecto Eleusio, regnante Domino nostro Iesu Christo, cui est gloria in saecula saeculorum, Amen. (Lapidge 2003: 165)

[III. 22. While the governor Eleusius, however, was sailing to his estate, a mighty tempest came and swamped his boat, and twenty-four men died, and when the water had cast them up in a desert place their bodies were devoured by beasts and birds. Saint Juliana was martyred on the fourteenth day before the Kalends of March, at the hands of the governor Eleusius in the reign of our Lord Jesus Christ, to whom is glory forever and ever. Amen.]

Cynewulfs rendering of this scene, by contrast, is substantially embellished through the deployment of a number of words, phrases and motifs common to Old English poetry and, more specifically, Beowulf:

$$
\begin{aligned}
& \qquad \overline{p a} \text { sè syn-scapa } \\
& \text { tō scipe sceōb-mōed sceapena prēate } \\
& \text { Heliseus èb-strēam sōbte, }
\end{aligned}
$$

in Beowulf, in the accounts of the departures of Scyld (32b) and Beowulf (1897b) from the Danes, and the description of Hengest's inability to sail back to the Danes from Frisia during the frozen winter (1131a).

${ }^{15}$ On the sources of Juliana, see Calder \& Allen (1976: 121-122), Woolf (1978), Lapidge (2003). Noting this departure from the Latin source, Lenore MacGaffey Abraham comments that in this passage, Eleusius and his men "like Vikings, take to the sea by the "swanroad", suggesting that he was forced into exile due to his having been "proved wrong" at Juliana's trial-by-ordeal and abused the legal process, thereby losing "all claim to legitimate rule". MacGaffey Abraham (2001: 186-187) further argues that Cynewulfs version of Eleusius' punishment, in which he floats at sea for a long time before drowning, "is reminiscent of the cold water ordeal". 
lèolc ofer lagu-flōd longe bwīle

on swon-räde. Swylt ealle fornom

secga hlōpe ond hine sylfne mid,

æxrpon hȳ tō lande geliden hæfdon,

purh pearlic prēa. p’èr prītig wæs

ond fēowere ēac fēores onsōhte

purh wǣges wylm wigena cynnes,

bēane mid bläford, brōpra bidēeled,

bybta lēase helle sōhton.

(Juliana, 671-682) (emphasis added)

[Then the harmful attacker Eleusius, with a host of ravagers, went to the ship, sought out the water-stream, troubled in mind, floated across the sea's flood for a long time, on the swan's riding. Death took all of them, the troop of warriors, and himself with them, before they had reached land, as a terrible punishment. There thirty-four of the kin of warriors were deprived of life through the surging of water, retainers with their lord, deprived of comfort, hopeless, they sought out hell.]

Several elements of the motif of 'the departure of the hero in a ship' are in play here: the (anti-)hero is again accompanied to the shore by his retainers, where a ship stands waiting. Fittingly, given the wretched state of the departing group, on this occasion there is no loading of treasure or praise of the departed and it is the departing Eleusius himself and his men, rather than those they have left behind, who are miserable (sceōb-mōd [...] brōpra bidēled, bybta lea ase). Further evidence for a direct textual link between this passage and Beowulf is provided by a striking cluster of lexical parallels. For example, Eleusius travels sceapena prēate, 'with a host of ravagers', while Scyld Scefing terrorised the neighbouring tribes sceapena preatum, 'with hosts of ravagers' $(4 \mathrm{~b}) ;{ }^{16}$ the governor's journey on swon-rāde, 'on the swan's road', echoes the extension of Scyld's power ofer brōn-rade, 'over the whale-road' (10a), as well as Beowulf's subsequent journey to the Danes ofer swan-räde, 'over the swanroad' (200a); ${ }^{17}$ both Eleusius and Grendel are referred to as a syn-scapa, 'sinful

\footnotetext{
${ }^{16}$ These are the only two collocations of these terms in the Old English poetic corpus.

${ }^{17}$ Similar collocations occur in Andreas (821a: on bron-räde) and Genesis A (205a: geond bron-rāde).
} 
ravager' (Juliana 671a, Beowulf 801b) ${ }^{18}$ while the governor, together with his men, brōpra bidēled [...] belle sōbton 'deprived of comfort [...] sought out hell', just as Grendel, drēamum bedēled, 'deprived of joys' (721a), wished sècan dèofla gedrēg, 'to seek out the company of devils' (756a), after receiving a mortal wound from Beowulf, before finally bim bel onfèng, 'hell received him' (852b). It appears, therefore, that in this section of Juliana, Cynewulf sought to present Eleusius and his men as Satanic villains whose departure goes un-mourned through imaginative use of the motif of the 'departure of the hero in a ship', as well as a range of further Beowulfian echoes. ${ }^{19}$

A further, albeit more tangential, variant on this motif is found in another Exeter-Book poem bearing Cynewulf's signature, Christ II (Ascension). In this poem's climactic scene, the Ascension of Christ, we find two of the typical features of the motif, namely the grief or those left behind and a song of praise for the departed, though the usual details of the awaiting ship and the loading of treasure are, of course, absent:
Him wes geömor sefa
bāt at heortan, byge murnende,
pres pe hī swà lēofne leng ne mōstun
gesēon under swegle. Song aböfun
àras ufancunde, apeling heredun,
lofedun lîf-fruman, lēohte gefēgun
pe of pres hǣlendes heafelan lixte.
(Cbrist II, 409-505) (emphasis added)

[They were sad in spirit, hot in the heart, grieving in the mind, because they could no longer see the beloved one under the heavens. They raised up a song, celestial messengers, praised the prince, glorified the Life-Creator, rejoiced in the light that shone from the head of that Saviour.]

\footnotetext{
${ }^{18}$ These are the only two occurrences of this compound in the Old English poetic corpus.

19 In her edition of Juliana, Rosemary Woolf (1978: 5) notes the presence of "reminiscences" of Beowulf, "which appear to be the result of deliberate imitation, rather than to be coincidental similarities arising from the borrowing from a common poetic stock". Woolf provides a list of sixteen of "the most important parallels" between the two texts (19), though none of her examples are taken from the passage discussed above. For an extensive list of parallels between all the Cynewulfian poems, Beowulf and Andreas, see Orchard (2003a).
} 
In none of the biblical accounts (Ps. 23, Mat. 28.16-20; Mark 16.14-20; Luke 24.36-53, Acts 1.1-14) or the various other Latin analogues and possible sources do we find comparable details. ${ }^{20}$ The Gospel of Matthew, for example, simply states that, after Christ has ascended to heaven, the disciples "going forth preached everywhere" (Mat. 16.20), while Luke similarly records "[a]nd they adoring went back into Jerusalem with great joy” (Luke 24.52). Although this is admittedly a much fainter echo than the examples discussed above, it appears, nevertheless, that Cynewulf has again borrowed some elements of 'the departure of the hero in a ship' for a specific purpose. In an inversion of the motif, the disciples' grief at their Lord's departure is offset by their knowledge of Christ's resurrection, symbolised by the shining light that surrounds His head. Hence, while the pagan Danes had lamented their lord's passing, ignorant of the final destination of Scyld's funeral ship (Beowulf, 50-52), the disciples rejoice (gefégun) at their Lord's departure, confident in their knowledge that Christ has ascended to heaven.

\section{Andreas}

It is now generally accepted that the author of the Vercelli Book verse saint's life poem Andreas drew on Beowulf, and perhaps Cynewulf, in adapting his main Latin source, a now-lost version of the apocryphal Acts of Andrew and Matthew. ${ }^{21}$ The two nearest surviving analogues are an early Greek version of

\footnotetext{
${ }^{20}$ On the sources of Christ II, see Calder \& Allen (1976: 78).

${ }^{21}$ The case for the Andreas-poet borrowing directly from Beowulf was first advanced in the late nineteenth century by Arthur Fritzche (1879: 493), and gained support from George P. Krapp (1906: li-lviii) who, in his 1906 edition, noted some 145 verbal parallels between the two poems, in addition to various parallels in plot and theme. Klaeber (1950: cxi) agreed that "the legend of Andreas exhibits abundant and unmistakable signs of having been written with Beowulf as a model". With the advent of oral-formulaic theory in the 1950s, the consensus shifted towards the position that any such parallels were simply the result of a shared oral tradition which provided poets with a store of words, phrases and 'type scenes' from which to build their works (Magoun 1953; Peters 1951: 847, 851). See, however, Kennedy (1943: 267-281), Lumiansky (1949: 116-126), Schaar (1956: 305), Stanley (1961: xx-xxiii), Riedinger (1993), Powell (2002), Orchard (2003a; 2003b: 82-83, 164; 2016), North \& Bintley (2016: 57-81).
} 
the Acts (Praxeis) and a Latin text preserved in the twelfth-century Codex Casanatensis, while an Old English prose life of Andrew is incorporated into Blickling Homily 29. ${ }^{22}$ Some commentators have found the Andreas-poet's use of seemingly stray words and phrases from Beowulf incongruous or dissonant with the work's religious theme (Stanley 1966: 114). However, others have defended its author as a conscious artist who adapted both his Latin and vernacular sources in order to transform the saint into a miles Christi (Kennedy 1943: 279, Hamilton 1975: 82-86, Herbison 2000). More recently, Andy Orchard (2016: 347) has described the Andreas-poet as "an idiosyncratic artist" who "invites his sensitive audience to identify his allusions [...] well aware of his place in the developing sequence of Anglo-Saxon poetry and confident of his own contribution", 23 while Francisco Rozano-García (2017: 194) goes further in describing Andreas as "a masterly exercise of assimilative and allusive technique". In the discussion that follows, I argue that the Andreas-poet's use of the motif of 'the departure of the hero in a ship' should be understood as a meaningful allusion to both Beowulf and the works of Cynewulf, rather than simply a reflex of Old English poetic tradition.

The motif first appears in Andreas as the saint sets off from his home in Achaia to Mermedonia, a land inhabited by a race of pagan cannibals, after receiving a command from God in a dream to rescue St Matthew from prison there. In the analogues, the saint's departure is dealt with relatively briefly: in the Casanatensis ch. 5, for example, Andrew goes walking by the shore as the Lord had commanded; he sees a little boat on the waves with three men on board (subsequently identified as Jesus and two angels); the Lord guides the boat ashore and Andrew asks the pilot (Jesus) if the sailors will convey him to Mermedonia; Andrew then boards the boat with his disciples and sits down near the pilot (Calder \& Allen 1976: 17-18). The Praxeis offers a similar account, though here the saint is accompanied to the shore by his men (MacDonald 1990: 3-5). In Andreas, by contrast, the scene is amplified through the inclusion of several elements of 'the departure of the hero in a ship':

\footnotetext{
${ }^{22}$ For the Praxeis, I cite the translation of MacDonald (1990). For the Greek text of the Praxeis, see Tischendorf, II.1 (1959: 65-116). For the Casanatensis, quotations are taken from Blatt (1930) (Latin text) and Boenig (1991) (translation).

${ }^{23}$ See further Rozano-García (2017) and North (2018).
} 
Gewāt him pā on ūhtan mid $\bar{x}$-dæge

ofer sand-hleoðu tō sēs faruðe,

prīste on gepance, ond bis pegnas mid,

gangan on grēote; gār-secg hlynede,

bēoton brim-strēamas. ${ }^{24}$ Sē beorn wæs on hyhte,

syðpan hē on waruðe wìd-feðme scip

mōdig gemētte. pā cōm morgen-torht

bēacna beorhtost ofer breomo snēowan,

hālig of heolstre heofon-candel blāe ${ }^{25}$

ofer lago-flōdas. Hē ð̄̄er lid-weardas,

prymlīce prỳ pegnas mètte,

mōdiglīce menn, on mere-bāte

sittan sīo-frome, swylce hìe ofer sǣ cōmon;

pæt wæs drihten sylf, dugeða wealdend,

èce ælmihtig, mid his englum twām.

Wæ̈ron hie on gescirplan scip-ferendum,

eorlas onlīce èa-lī̌endum,

ponne hīe on flōdes fæðm ofer feorne weg

on cald wæter cēolum lācað.

(Andreas, 235-253) (emphasis added)

[He took himself then at dawn, before day, over sandy dunes to the edge of the sea, determined in spirit, with his thanes, walking on the gravel; the ocean roared, water-streams clashed. The warrior was hopeful once he, proud on the shore, saw on the waves a broad-bosomed ship. Then came the radiant morning, brightest of beacons, hastening over the deep, the heaven-candle shone holy from out of the darkness over the water-floods. He found there sea-guardians, three brave ones, proud men, sitting in a sea-boat eager to set sail after they had come out of (or across) the sea; that was the Lord Himself, Ruler of Troops, Eternal Almighty, with his two angels. They were dressed as sailors, in the likeness of warriors, ship-travellers, when they launch their boats into the flood's embrace, into cold water, from foreign shores.]

\footnotetext{
${ }^{24}$ The rare compound brim-strēam occurs only on two further occasions in Andreas (348a, 903b), once in Beowulf (1910b) and once in the The Capture of the Five Boroughs (5a). Cf. Juliana 673b: êh-stream.

${ }^{25}$ Note the presence of this feature of 'the hero on the beach'; see Crowne (1960).
} 
As in Scyld's funeral, the hero takes himself (Gewät him) to the shore along with his companions. However, only in Beowulf, Cynewulf and Andreas do we find a description of the wid-farme scip awaiting the departing hero on the shore; in the Latin and Greek analogues, by contrast, the saint first spies the boat out at sea. As in Elene, the saint's departure does not inspire grief, as he too is doing God's work in setting sail for Mermedonia. Moreover, in a further echo of the departures of Scyld and Elene, the Andreas-poet expresses his wonder at the ship's cargo:

Gesæt him pā sē hālga holm-wearde nēah, æðele be æðelum; āfre ic ne bȳrde pon cymlīcor cēol gebladenne bēah-gestrēonum. Hæleð in sǣton, pēodnas prym-fulle, pegnas wlitige. (Andreas, 359-363) (emphasis added)

[The saint then sat himself down next to the ship's captain, one nobleman alongside another; never bave I heard of a comelier ship laden with valuable treasures. The warriors sat down, a people full of might, splendid thanes.]

As North \& Bintley (2016: 231) observe, the treasures loaded onto Andreas's ship are its human passengers, rather than the physical treasures that accompany Scyld into the deep. Moreover, as we have seen, Cynewulfs description of the loading of Elene's ship both with treasures and human cargo mediates between Beowulf and Andreas. In this way, the Andreas-poet follows Cynewulf in employing Beowulfian allusions in order to convey his Christian message that the apostolic mission is a heroic endeavour as worthy of praise as the great pagan kings of old - if not more so.

While there are interesting parallels between this passage and the various scenes discussed above in Beowulf and Cynewulf, it is in the poem's closing lines that the Andreas-poet engages most deeply with the motif of 'the departure of the hero in a ship'. In describing how the saint, having converted the Mermedonians, leaves their shores and sails back to Achaia, the Andreaspoet appears to have drawn on all three of the main departure-scenes in Beowulf discussed above, as well, perhaps, as Cynewulf's account of the apostles' grief at Christ's ascension in Christ II. In repurposing these vernacular sources, combining echoes of Beowulf and Cynewulf, and indeed of Cynewulf echoing Beowulf, and bringing them to bear on his primary Latin 
source, the Andreas-poet produced a fitting conclusion to his own poem, glorifying the triumphs of the apostles and the eternal power of their king.

In the Greek, Latin and Old English analogues, the saint's departure from the Mermedonians is again dealt with relatively briefly. After Andrew has converted the former race of cannibals and established a church where his own prison had once stood, the Mermedonians beg him to stay longer so that they can learn more about their new faith (Praxeis/Casanatensis, ch. 32). But despite their protestations and weeping at his imminent departure, the saint is determined to return home to his disciples, until Christ, in the form of a small child, instructs Andrew to remain with them for a further seven days. In the Casanatensis ch. 33, for example, we read:

Andreas vero reversus est in mermedonia, benedicens dominum et ait, gratias ago tibi domine meus iesu christe, qui vis omnes animas salvas fieri, et ad agnitionem veritatis venire. Populus autem cum vidisset eum reverti, obviantes ei cum gloria, magnoque gaudio letantes, domini gratie referentes, qui exaudierat eos lacrimantes, voceque eum clamantes. Beatus vero andreas mansit cum illis diebus septem, predicans et docens eos verbis salutis domini iesu christi, conformans eos in integram fidem catholicam, sicuti iussum est ei a domino iesu christo. Post expletos septe dies, profectus est et habiit inde. Cunctus autem populus mermedonie maximum usque ad minimum, propter magnam dilectionem habierunt cum eo, usque ad aliquantulum locum et reversi sunt in suam benedicentes et laudantes dominum dicentes, unus est deus, quem nobis manifestavit beatus andreas apostolus eius dominum nostrum iesum christum, cui est honor et gloria, in secula seculorum, Amen. (Blatt 1930: 95)

[Then truly Andrew went back into Mermedonia, blessing the Lord. And he said, 'I thank you, my Lord Jesus Christ, who can save all souls and bring them to knowledge of the truth.' And when the people saw him return, they met him with glory and rejoiced with great joy, giving back thanks to the Lord who had listened to their tears and their crying voices. Indeed the blessed Andrew remained with them seven days, preaching and teaching them with his words the salvation of the Lord Jesus Christ, confirming them in the pure catholic faith, just as the Lord Jesus Christ had commanded him. After the seven days were over, he departed and left. But all the Mermedonian people, from the greatest to the least, on account of their great love, went with him to a certain little place and returned to their own, blessing and praising God and saying, 'God is one, whom the blessed Apostle Andrew manifested to us, his Lord our 
Jesus Christ, to whom be honor and glory, forever and ever. Amen.' (Boenig 1991: 54-55)]

The Praxeis ch. 33 presents a similar, even shorter, account of the saint's departure (MacDonald 1990: 167-169), while Blickling Homily 29 adds the detail that Andrew was led to the shore by the Mermedonians:

Se eadiga Andreas pa wæs eft hwyrfende on Marmadonia ceastre, and he cwæð, 'Ic pe bletsige min Drihten Hælend Crist, pu pe gehwyrfest ealle saula, forpon pu me ne forlete ut-gangan mid minre hat-heortan of pisse ceastre.' Hio wæron geofende mycle gefean, and he pær wunode mid him seofn dagas, lærende and strangende hira heortan on geleafan ures Drihtnes Hælendes Cristes.

Mid pi pe pa wæron gefyllede seofon dagas swa swa him Drihten bebead, he ferde of Marmadonia ceastre efstende to his discipulum. And eall pæt folc hine lædde mid gefean and hie cwædon, 'An is Drihten God, se is Hælend Crist, and se Halga Gast, pam is wuldor and geweald on pære Halgan prynnysse purh ealra worulda woruld soðlice a butan ende.' (Morris 1880: 249)

[When he had said this, the Lord Jesus Christ ascended up to heaven, and the blessed Andrew returned to the city of Mermedonia and said, 'I bless you, my Lord Jesus Christ, you who turns all souls to you, that you did not let me depart in my anger from this city.' And the people rejoiced with great joy. And he dwelt with them there for seven days, teaching and confirming their hearts in the faith of our Lord Jesus Christ.

When the seven days were fulfilled, as the Lord had commanded him, he departed from the city of Mermedonia, hastening to his disciples. And all of that people led him forth with joy and they said, "There is one Lord God, he is Christ the Saviour, and the Holy Spirit, to whom is glory and power in the Holy Trinity, through all of the world, truly world without end.']

The Andreas-poet, however, again presents a greatly expanded account of the scene, including a number of details which do not appear in any of the analogues: $:^{26}$

${ }^{26}$ Andreas presents a similarly expanded account of Andrew's seven extra days among the Mermedonians (1675-1705, esp. 1687-1696, on the razing of heathen structures). Brooks (1961: 118) attributes this expansion to the Andreas-poet; North \& Bintley (2016: 304-305), on the other hand, suggest that the poet here follows his now-lost source. 
Đā ic lǣ̉an gefrægn lēoda weorode lēofne lārēow tō lides stefnan, mæcgas mōd-geōmre. p̄ōr manegum wæs hāt æt heortan hyge weallende.

Hīe ðā gebrōhton æt brimes næsse on wēg-pele wigan unslāwne; stōdon him ðā on ōfre æfter rēotan, pendon hie on ỳðum æxolinga wunn ofer seolh-paðu gesēon mihton, ond pā weorðedon wuldres āgend, cleopodon on corðre, ond cwǣdon pus:

'Ān is ēce god eallra gesceafta! Is his miht ond his $\bar{x} h t$ ofer middan-geard brēme gebledsod, ond his blǣd ofer eall in heofon-prymme hālgum scīneð, wlitige on wuldre tō wìdan aldre, ēce mid englum; pæt is æðele cyning!' (Andreas, 1706-1722)

[Then I heard that hosts of people led their beloved teacher to the vessel's prow, warriors dejected in spirit. For many there the thoughts were welling hot in the heart. Then at the headland of the sea they brought aboard the boat the brave warrior; they stood themselves along the shore weeping in his memory for as long as they could see the joy of princes on the waves, over the seal-path, and then they worshipped the Owner of Glory, called out among the crowds, and said thus: 'There is one Eternal God of All Creation! His might and his power are widely blessed in renown over middle-earth and his glory shines over all in the might of heaven, splendidly in glory for all time, eternal with the angles; that is a Noble King!']

Only in Andreas and the Blickling Homily do the Mermedonians lead Andrew to the shore; in the Greek and Latin analogues, by contrast, they follow the saint and travel with him. The presence of several further narrative elements, however, suggests that the poet is drawing here on the motif of 'the departure of the hero in a ship': 
(1) the Mermedonians grieve at the saint's departure, whereas in all the analogues they greet his departure with joy; ${ }^{27}$

(2) the means of Andreas's departure, by boat, is emphasised, and the prow of his ship is mentioned (lides stefnan), whereas in the other accounts the boat is not described at all and Andrew simply departs from Mermedonia;

(3) in Andreas alone God is praised, in distinctly royal terms, in the expanded doxology, structured around an envelope pattern on the term ece; the final theme of Andreas is the eternal kingship of Christ.

Parallels between Andreas's leave-taking and Scyld's ship-funeral have been noted in passing, ${ }^{28}$ but the full significance of this connection, and the implications of links with the other two Beowulfian passages, have thus far received little critical attention. ${ }^{29}$ Peters, for example, dismisses the possibility that the Andreas-poet had the end of Beowulf in mind when composing his own closing section on the grounds that the saint's leave-taking "bears no resemblance to the funeral rites of Beowulf upon Hronesnesse at the end of the epic" (1951: 849).$^{30}$ However, as we have seen, there is in fact a number of striking connections between Andrew's departure from Mermedonia not only to Beowulfs closing lines but also to the earlier departure-scenes of both Scyld

\footnotetext{
${ }^{27}$ Though in the preceding chapter (32) of Praxeis/Canatensis, the Mermedonians had wept at Andrew's proposed departure, before Christ instructs his to stay for a further week.

${ }^{28}$ Brooks (1960: xxiii), Orchard (2003a: 164).

${ }^{29}$ None of these passages from Andreas or Beowulf appear, for example, in Schaar's (1956: 304) list of passages containing "parallels most of which I am inclined to regard as literary borrowings", despite the majority of these passages being from Andreas and Beowulf. Kennedy (1943: 269) notes: "In each poem [Beowulf and Andreas], when the triumph is won, the story is rounded out by the hero's preparation for departure, the general grief at his going, and the return voyage by which he sails back to the land from which he came. In each poem, the final scenes are laid upon a sea-headland looking out over the ocean". Kennedy does not discuss parallels between the departures of Scyld and Beowulf from the Danes and Andrew's departure from the Mermedonians.

${ }^{30}$ Peters (1951: 848) similarly dismisses the significance of parallels between Andrew's preparations to leave the Mermedonians and Beowulfs departure from the Danes on the grounds that "the Andreas-poet is clearly following the apocryphal gospel rather than Beowulf".
} 
and Beowulf from the Danes, as well as the various Cynewulfian departurescenes. It is, of course, possible that the Andreas-poet drew here on a now-lost Latin source, an intermediary between the Praxeis and Casanatensis, in which these narrative details unique to the poem were present. ${ }^{31}$ Alternatively, Shannon Godlove (2016: 197) has recently suggested that in embellishing the account of the saint's leave-taking, the Andreas-poet is "playing with the type scenes of departure common in Old English heroic poetry" ${ }^{32}$ However, as we have seen, within the Old English poetic corpus 'the departure of the hero in a ship' is otherwise confined to Beowulf and two of the four signed poems of Cynewulf, texts which the Andreas-poet is known to have made use of elsewhere. ${ }^{33}$ This correlation suggests that the Andreas-poet was not simply drawing on Old English literary convention but rather that he was alluding to these specific works in a knowing manner.

\section{Conclusion}

This article has identified a new Old English poetic motif, 'the departure of the hero in a ship', common to Beowulf, the signed poems of Cynewulf and Andreas. The 'co-presence' of this motif in this group of texts provides further evidence of their intertextuality. Whereas in Beowulf the motif serves as a frame to the entire work, highlighting key moments in the royal succession and providing a platform for characters to praise ancient pagan kings and xthelings, in the hands of Cynewulf and the Andreas-poet the same motif is put to a different use, to glorify the disciples and saints or to condemn those, like Eleusius, who would hinder the church's mission. The knowledgeable

\footnotetext{
${ }^{31}$ See North \& Bintley (2016: 6).

${ }^{32}$ See also Crowne (1960: 372).

33 The description of the sea-borne departure of Noah in Genesis A (1356-1391) does not correspond in any substantial way with 'the departure of the hero in a ship'. However, the departure of the saint's messenger the end of Gutblac B, a poem which is closely linked with the Cynewulf group, does feature several of the key elements of the motif with some significant variations: the messenger, unaccompanied, departs on a boat, consumed by sorrow for his dead master (508b-525); on arriving at the house of Guthlac's sister, he sings a song of praise for his departed lord, lamenting his own lot (530-556a). As such, this passage may be considered an inversion of the motif, emphasising the messenger's desolation at the saint's departure.
} 
Anglo-Saxon audience of these works was not only expected to recognise the allusion to Beowulf but also to admire how these poets had deftly adapted a secular motif for a higher, spiritual purpose.

\section{References}

Acta Cyriaci = Acta Sanctorum, Maius, Tom. I. 1680. Antwerp, Societé des Bollandistes. Cols 445-448.

Alfaro, M. J. M. 1996: Intertextuality: Origins and Development of the Concept. Atlantis 18: 268-285.

Battles, P. 2015: Dying for a Drink: 'Sleeping after the Feast' Scenes in Beowulf, Andreas and the Old English Poetic Tradition. Modern Pbilology 112: 435-457.

Benson, L. D. 1995: The Literary Character of Anglo-Saxon Formulaic Poetry. In T. M. Andersson \& S. A. Barney eds. Contradictions: From Beowulf to Chaucer: Selected Studies of Larry D. Benson. Aldershot (Hants) \& Brookfield (VT), Ashgate: 5-31.

Blatt, F. ed. 1930: Die lateinischen Bearbeitungen der Acta Andreae et Matthiae apud Anthropophagos, Beihefte zur Zeitschrift für neutestamentliche Wissenschaften 12. Giessen, Töpelmann.

Boenig, R. ed. and trans. 1991: The Acts of Andrew in the Country of the Cannibals: Translations from Greek, Latin, and Old English. Garland Library of Medieval Literature, 70.B. New York \& London, Routledge.

Bonjour, A. 1957: Beowulf and the Beasts of Battle. Proceedings of the Modern Languages Association 72: 563-573.

Borgehammar, S. 1991: How the Holy Cross Was Found: From Event to Medieval Legend. Stockholm, Almquist \& Wiksell International.

Calder, D. G. \& M. J. B. Allen trans. 1976: Sources and Analogues of Old English Poetry: The Major Latin Texts in Translation. Cambridge: D. S. Brewer.

Cameron, A. F. 1969: Saint Gildas and Scyld Scefing. Neuphilologische Mittelungen 70: 240-246.

Classen, A. 2012: The Symbolic and Metaphorical Role of Ships in Medieval German Literature: A Maritime Vehicle that Transforms the Protagonist. Mediaevistik 25: 15-33.

Clark, G. 1965: The Traveler Recognizes His Goal: A Theme in Anglo-Saxon Poetry. Journal of English and Germanic Philology 64: 645-659.

Crowne, D. K. 1960: The Hero on the Beach: An Example of Composition by Theme in Anglo-Saxon Poetry. Neuphilogische Mitteilungen 61: 362-372.

Fritzsche, A. 1879: Das angelsächsische Gedicht Andreas und Cynewulf. Anglia 2: 441-496. 
Fry, D. K. 1966: The Heroine on the Beach in Judith. Neuphilogische Mitteilungen 67: 27-31.

Fry, D. K. 1971: Type-Scene Composition in Judith. Annuale Mediaevale 12: 100-119.

Fulk, R. D., R. E. Bjork \& J. D. Niles eds. 2008: Klaeber's 'Beowulf and 'The Fight at Finnsburg': Fourth Edition. Toronto, University of Toronto Press.

Gardner, J. 1970: Cynewulfs Elene: Sources and Structure. Neophilologus: 65-75.

Genette, G. 1997: Palimpsests: Literature in the Second Degree. [C. Newman \& C. Doubinsky transl.] Lincoln (NA), University of Nebraska Press.

Godlove, S. 2016 for 2015: The Reluctant Apostle: Heroic Rhetoric and Human Frailty in the Old English Andreas. Medieval Perspectives: Journal of the Southeastern Medieval Association 30: 183-208.

Gradon, P. O. E. ed. 1996: Cynewulfs Elene. Exeter, Exeter University Press.

Greene, E. S. 1995: The Critical Element in the Embarkation Scenes of the Odyssey. Greek, Roman and Byzantine Studies 36: 217-230.

Griffith, M. S. 1993: Convention and Originality in the Old English "Beasts of Battle" Typescene. Anglo-Saxon England 22: 179-199.

Grocock, C. \& I. N. Wood ed. and trans. 2013: Abbots of Wearmouth and Jarrow: Bede's Homily i.13 on Benedict Biscop; Bede's History of the Abbots of Wearmouth and Jarrow; The Anonymous Life of Ceolfrith; Bede's Letter to Ecgbert, Bishop of York. Oxford, Clarendon Press.

Hamilton, D. 1975: Andreas and Beowulf: Placing the Hero. In L. E. Nicholson \& D. W. Frese eds. Anglo-Saxon Poetry: Essays in Appreciation. Notre Dame (IN), University of Notre Dame Press: 81-98.

Herbison, I. 2000: Generic Adaptation in Andreas. In J. Roberts \& J. Nelson eds. Essays on Anglo-Saxon and Related Themes in Memory of Lynne Grundy (King's College London Medieval Studies 17). Exeter, King's College London, Centre for Late Antique and Mediaeval Studies: 181-211.

Hill, J. M. 2008: The Narrative Pulse of 'Beowulf: Arrivals and Departures. Toronto, University of Toronto Press.

Hughes Funk, C. 1998: History of Andreas and Beowulf: Comparative Scholarship. (Ph.D. dissertation.) University of Denver.

Kail, J. 1889: Über die Parallelstellen in der angelsächsischen Poesie. Anglia 12: 21-40.

Kennedy, C. 1943: The Earliest English Poems: A Critical Survey of the Poetry Written Before the Norman Conquest with Illustrative Translations. Oxford, Oxford University Press.

Klaeber, F. ed. 1936, supplemented 1941 and 1950 = 1950: 'Beowulf' and 'The Fight at Finnsburg'. 3rd ed. Boston, Heath.

Krapp, G. P. ed. 1906: 'Andreas' and 'The Fates of the Apostles': Two Anglo-Saxon Narrative Poems. Boston, Ginn \& Company.

Kristeva, J. 1986: Word, Dialogue and Novel. [A. Jardine, T. Gora \& L. S. Roudiez transl.] In T. Moi ed. The Kristeva Reader. New York, Columbia University Press: 
34-61.

Lapidge, M. 2003: Cynewulf and the Passio S. Iulianae. In M. C. Amodio ed. Unlocking the Wordhord: Anglo-Saxon Studies in Memory of Edward B. Irving Jr. Toronto, University of Toronto Press: 147-171.

Leneghan, F. Forthcoming: The Dynastic Drama of 'Beowulf. Cambridge, D. S. Brewer.

Leyser, H. 2017: A Short History of the Anglo-Saxons. London, I. B. Tauris.

Luehrs, P. M. 1904: A Summary of Sarrazin's 'Studies in Beowulf'. Western Reserve University Bulletin 7: 146-165.

Lumiansky, R. M. 1949: The Contexts of Old English Ealuscerwen and Meoduscerwen. Journal of English and Germanic Philology 48: 116-126.

MacDonald, D. R. ed. 1990: The Acts of Andrew and the Acts of Andrew and Matthias in the City of the Cannibals (Texts and Translations 33, Christian Apocrypha 1). Atlanta (GA), Scholars Press.

MacGaffey Abraham, L. 2001: Cynewulf's Juliana: A Case at Law. In R. E. Bjork ed. The Cynewulf Reader (Basic Readings in Anglo-Saxon England 4). New York, Routledge: 171-192.

Magennis, H. 2018: Cristes leorningcnibtas: Traditions of the Apostles in Old English Literature. In M. Cesario \& H. Magennis eds. Aspects of Knowledge: Preserving and Reinventing Traditions of Learning in the Middle Ages. Manchester, Manchester University Press: 97-115.

Magoun Jr., F. P. 1953: Oral-Formulaic Character of Anglo-Saxon Narrative Poetry. Speculum 28: 446-467.

Magoun Jr., F. P. 1955: The Theme of the Beasts of Battle in Anglo-Saxon Poetry. Neuphilogische Mitteilungen 56: 81-90.

McFadden, B. 2000: Sleeping after the Feast: Death Beds, Marriage Beds, and the Power Structure at Heorot. Neophilologus 84: 629-646.

Meaney, A. L. 1988: Scyld Scefing and the Dating of Beowulf-Again. Bulletin of the Jobn Rylands University Library of Manchester 71: 7-40.

Morris, R. ed. and trans. 1880: The Blickling Homilies of the Tenth Century. London, N. Trübner \& Co.

North, R. \& M. D. J. Bintley eds. 2016: Andreas: An Edition. Liverpool, Liverpool University Press.

North, R. 2018: Meet the Pagans: On the Misuse of Beowulf in Andreas. In M. Cesario $\&$ H. Magennis eds. Aspects of Knowledge: Preserving and Reinventing Traditions of Learning in the Middle Ages. Manchester, Manchester University Press: 185-209.

Orchard, A. 2003a: Both Style and Substance: The Case for Cynewulf. In C. E. Karkov \& G. Hardin Brown eds. Anglo-Saxon Styles. Albany (NY), SUNY Press: 271-305.

Orchard, A. 2003b: A Critical Companion to 'Beowulf. Cambridge, D. S. Brewer.

Orchard, A. 2016: The Originality of Andreas. In L. Neidorf, R. J. Pascual \& Tom 
Shippey eds. Old English Philology: Studies in Honour of R. D. Fulk. Cambridge, D. S. Brewer: 331-370.

Orchard, A. Forthcoming. Alcuin and Cynewulf: The Art and Craft of Anglo-Saxon Verse (Sir Israel Gollancz Memorial Lecture). Proceedings of the British Academy.

Owen-Crocker, G. 2000: The Four Funerals in 'Beowulf and the Structure of the Poem. Manchester, Manchester University Press.

Peters, L. J. 1951: The Relationship of the Old English Andreas to Beowulf. Proceedings of the Modern Languages Association 66: 844-863.

Powell, A. 2002: Verbal Parallels in Andreas and its Relationship to Beowulf and Cynewulf. (Ph.D. dissertation.) University of Cambridge.

Ramsey, L. C. 1971: The Sea Voyages in Beowulf. Neuphilologische Mitteilungen 72: 5159.

Riedinger, A. 1993: The Formulaic Relationship between Beowulf and Andreas. In H. Damico \& J. Leyerle eds. Heroic Poetry in the Anglo-Saxon Period: Studies in Honor of Jess B. Bessinger (Studies in Medieval Culture 32). Kalamazoo (MI), Medieval Institute Publications: 283-312.

Rozano-García, F. J. 2017: Hwēer is wuldor pin?: Traditional Poetic Diction and the Alien Text in the Old English Andreas. Peritia 28: 177-194.

Salvador Bello, M. 1998: The Arrival of the Hero in a Ship: A Common Leitmotif in OE Regnal Tables and the Story of Scyld Scefing in Beowulf. SELIM 8: 205-222.

Sarrazin, G. I. 1886: Beowulf und Kynewulf. Anglia 9: 515-550.

Sarrazin, G. I. 1888: Beowulf-Studien; ein Beitrag zur Geschichte altgermanischer Sage und Dicbtung. Berlin, Mayer \& Müller.

Schaar, C. 1956: On a New Theory of Old-English Poetic Diction. Neopbilologus 40: 301-305.

Scragg, D. G. 1997: Source Study. In K. O’Brien O'Keeffe ed. Reading Old English Texts. Cambridge, Cambridge University Press: 39-58.

Stanley, E. G. 1966: Beowulf. In E. G. Stanley ed. Continuations and Beginnings. London, Thomas Nelson: 104-141.

Tischendorf, C. ed. 1959: Acta Apostolorum Apocrypha, rev. R. A. Lipsius \& M. Bonnet. 2 vols. Hildesheim, Olms, II.1: 65-116.

Whitelock, D. 1949: Anglo-Saxon Poetry and the Historian. Transactions of the Royal Historical Society 31: 75-94.

Woolf, R. ed. 1978: Cynewulfs Juliana. Exeter, Exeter University Press.

Author's address

Faculty of English Language and Literature

University of Oxford

St Cross Building, Manor Road

Oxford, OX1 3UL

received: 1 May 2019

e-mail: francis.leneghan@ell.ox.ac.uk

revised version accepted: 1 June 2019 